\title{
Rheological behavior of blueberry
}

\author{
Comportamento reológico de mirtilo
}

\section{Graziella Colato ANTONIO ${ }^{1 *}$, Flávia Regina FARIA ${ }^{1}$, Cristina Yoshie TAKEITI ${ }^{1}$, Kil Jin PARK ${ }^{1}$}

\begin{abstract}
The physical and physicochemical characteristics of blueberry (Vaccinium myrtillus) fruits produced in Brazil were analyzed. Rheological properties were measured at $5,25,45$ and $65^{\circ} \mathrm{C}$, on a stress controlled rheometer equipped with grooved a stainless-steel parallel-plate in a shear rate range of $0-300 \mathrm{~s}^{-1}$, with the objective of determining the influence of temperature on the rheological properties. The pseudoplastic behavior with yield stress was well described by the Ostwald-de-Waele (Power Law), Herschel-Bulkley (HB) and Mizhari Berk models. The yield stress and behavior index decreased with the increase in the temperatures for 5,25 , and $45^{\circ} \mathrm{C}$ whereas for the temperature of $65^{\circ} \mathrm{C}$ the effects were the opposite exhibiting elevated values. The viscosity decreased with an increase in temperature, and the Arrhenius equation described adequately the effect of temperature on the apparent viscosity of the puree, in which the activation energy (Ea) determined at a shear rate of $100 \mathrm{~s}^{-1}$ was $9.36 \mathrm{~kJ} \cdot \mathrm{mol}^{-1}$.
\end{abstract}

Keywords: fruit; anthocyanin; viscosity; rheological equation; activation energy.

\section{Resumo}

As características físicas e físico-químicas do mirtilo (Vaccinium myrtillus) produzido no Brasil foram analisadas. As propriedades reológicas foram medidas em $5,25,45$ e $65^{\circ} \mathrm{C}$, em um reômetro de tensão controlada equipado com geometria rugosa de placas paralelas com taxa de deformação variando de $0-300 \mathrm{~s}^{-1}$ com o objetivo de verificação da influência da temperatura no comportamento do fluido. O comportamento pseudoplástico com tensão residual foi bem descrito pelos modelos de Ostwald-de-Waele (Lei da Potência), Herschel-Bulkley (HB) e Mizhari Berk. A tensão residual diminuiu com o aumento da temperatura para 5,25 e $45^{\circ} \mathrm{C}$, enquanto que para $65{ }^{\circ} \mathrm{C}$ os efeitos foram contrários, exibindo elevados valores. A viscosidade diminuiu com o aumento da temperatura e a equação de Arrhenius apresentou uma boa descrição do efeito da temperatura na viscosidade aparente do mirtilo, e a energia de ativação (Ea) determinada para uma taxa de deformação de $100 \mathrm{~s}^{-1}$ foi $9,36 \mathrm{~kJ} \cdot \mathrm{mol}^{-1}$.

Palavras-chave: fruta; antocianina; viscosidade; equações reológicas; energia de ativação.

\section{Introduction}

Blueberries have become very popular with consumers because of research findings that their consumption improves human health (KALT et al., 1999). The health benefits of berries may be partly attributed to their high content of phenolic compounds since phenolics possess a wide spectrum of biochemical activities such as antioxidant, antimutagenic, abilities to modify gene expression (NAKAMURA et al., 2003), as well as cardiovascular protection, antidiabetic properties, vision improvement properties, and inhibition of carcinogenesis.

Anthocyanins, natural pigments responsible for the blue, purple, violet, and red colors of fruit, are one of the major flavonoid classes. The major sources of anthocyanins in edible plants are the families Vitaceae (grape) and Rosaceae (cherry, plum, raspberry, strawberry, blackberry, apple, peach, etc.). Other plant families which contain anthocyanin pigments are Solanaceae (tamarillo and eggplant), Saxifragaceae (red and black currants), Cruciferae (red cabbage), and Ericaceae (blueberry and cranberry).
The blueberry is an almost unknown fruit in Brazil. The introduction of this fruit in the country began on the second half of the 80s, and the first commercial initiative occurred just after 1990.

Among the colored fruits, berries such as blackberry, raspberry, blueberry, cranberry, mulberry, and strawberry are consumed both in fresh and in processed forms.

It is important to understand the rheological behavior of blueberry purees, especially for processing and handling applications involving pumping and mixing (NINDO, 2007).

The rheological properties play an important role in the handling and quality attributes of minimally processed foods, such as fruit and vegetables. One of the most important characteristics of the rheological behavior is the material properties dependence on temperature (RAO; STEFFE, 1992).

It has been reported that fruit pulps behave as a nonNewtonian fluids (HOLDSWORTH, 1971). In general, purees of fruits and vegetables are pseudoplastic fluids (RAO, 1977). 
The influence of temperature on viscosity of non-Newtonian fluids may be expressed in terms of the Arrhenius-type equation (Equation 1), which involves the absolute temperature (T), the universal gas constant $R\left(8314 \mathrm{~J} \mathrm{~g}^{-1} \mathrm{~mol}^{-1} \mathrm{~K}^{-1}\right)$, the energy of activation for viscosity $\left(E_{\mathrm{a}}, \mathrm{J}_{\mathrm{mol}} \mathrm{m}^{-1}\right)$, the Arrhenius Constant B $\left(\operatorname{Pas}^{\mathrm{n}}\right)$, and the apparent viscosity $\eta$ (Pas) (STEFFE, 1996).

$\ln \eta=\left(\frac{E_{a}}{R}\right) \cdot T^{-1}+B$

Since there is a significant change in the apparent viscosity when the fruit puree is heated, Maceiras et al. (2006) studied the effect of cooking on the rheological behavior of raspberry, strawberry, peach, and prune and reported that the fruit purees studied have a non-Newtonian behavior, well described by the Ostwald-de-Waelle and Herschel-Bulkley (HB) models. The apparent viscosity was influenced by cooking decreasing with the temperature and increasing with the solid content.

The pseudoplastic behavior was also used to describe the whole and centrifuged mango and pineapple pulps' rheological behavior by Pelegrine et al. (2002), who fitted the data with Casson, Ostwald-de-Waelle and Mizrahi-Berk (M-B) models obtaining the best adjustment with M-B model.

Haminiuk et al. (2006) studied the influence of temperature on the rheological behavior of whole araça pulp and found that it was well described by the power law model with the pulp showing a pseudoplastic behavior and the apparent viscosity decrease with an increase in the shear rate and temperature as expected for liquid foods. The Arrhenius equation was used to describe the influence of temperature on the apparent viscosity. The activation energy value at a constant shear rate of $50 \mathrm{~s}^{-1}$ was $11.03 \mathrm{~kJ} \cdot \mathrm{mol}^{-1}$.

The rheological properties of another variety of blueberry Highbush blueberry (Vaccinium corymbosum L.) were previously studied by Nindo et al. (2007), who analyzed the influence of temperature and solid content on the rheological behavior of blueberry puree. The authors found a non-Newtonian behavior with shear-thinning characteristics. The Herschel-Bulkley (HB) model was efficient for the adjustment of the experimental data. The activation energy increased with total solids content from 11.4 to $17.1 \mathrm{~kJ} . \mathrm{mol}^{-1}$ for the purees with 10 and $25 \%$ total soluble solids, respectively, with respect to apparent viscosity determined at a shear rate of $100 \mathrm{~s}^{-1}$.

Since the rheological properties are important data in the definition of the processing operations and equipment design in food industry, the objective of this study was to determine the influence of temperature on the rheological behavior of blueberry puree and to determine the rheological equation that best describes the rheological behavior.

\section{Materials and methods}

\subsection{Sample preparation}

The blueberry fruits used in this work were obtained from Nutrisaúde Indústria e Comércio de Frutas Ltda., located in the city of Caxias do Sul in the state of Rio Grande do Sul, Brazil.
The fruits were at their perfect stage of maturation. They were selected and standardized for the analyses considering their size, firm texture, and absence of defects.

For the rheological analysis, the fruits were triturated in a household blender, kept in a household freezer $\left(-18{ }^{\circ} \mathrm{C}\right)$, and defrosted in a household refrigerator just before the experiment.

\subsection{Physical and physicochemical characterization}

The fresh fruits selected were physically characterized according to their weight and dimensions (height and diameter).

Moisture, soluble solids, protein, ash, $\mathrm{pH}$, total sugar, invert sugar, and titratable acidity were determined according to the standard method AOAC (1984); the $\mathrm{pH}$ was determined with a METTLE TOLEDO 320 model $\mathrm{pH}$ meter; the titratable acidity was expressed as a percentage of citric acid and was determined with $0.1 \mathrm{M} \mathrm{NaOH}$ up to $\mathrm{pH} 8.1$; the soluble dry matter was determined using a CARL ZEISS (JENA) 32-G 110d refractometer; the protein content was determined by the Kjeldal method (Nx6.25); and the total sugar and invert sugar contents were analyzed by the Lane-Eynon method.

The water activity was determined in an AQUALAB CX-2T DECAGON equipment at $25^{\circ} \mathrm{C}$.

The total content of anthocyanins was determined by the Francis (1982) method. Initially, an extraction of the pigments of a $1 \mathrm{~g}$ of the fruit sample of with $20 \mathrm{~mL}$ of extractor solution (methanol/HCl $1.5 \mathrm{M}$ in a $85: 15, \mathrm{v}: \mathrm{v}$, proportion) was done. The mixture was then homogenized in an IKA ULTRA TURRAX T8 basic homogenizer and kept refrigerated before the lecture of absorbance, which was done in the filtered extract in a BECK MAN DU-70 Spectrophotometer at wave length of $528 \mathrm{~nm}$. The whole process was performed protected from light, and the total anthocyanins (TA) was expressed in $\mathrm{mg} .100 \mathrm{~g}^{-1}$ of sample according to the Equation (2):

$T A=\frac{A b s_{\max } \times V}{E_{1 c m, \lambda_{\text {max }}}^{1 \%} \times W}$

where Absmáx = maximum absorbance; $V=$ volume $(\mathrm{mL}) ; E_{1 c m, \lambda}^{1 \%}=$ Extinction coefficient at $1 \%$, used by Lees and Francis (1972) for cranberry extract $=98.2$, and $W=$ sample weight $(\mathrm{g})$.

\subsection{Rheological measurements}

The flow curves of the blueberry puree were determined using a $\mathrm{CSL}^{2}$ 500-Carri Med rheometer. It was adopted the grooved stainless-steel parallel-plate, with $2 \mathrm{~cm}$ diameter and a gap of $1 \mathrm{~mm}$ between plates. The steady shear ( $\eta$ vs. $\dot{\gamma}$ ) experiments were conducted at increasing strain rate values ranging from 0 to $300 \mathrm{~s}^{-1}$ (up curve 1 ) followed by decreasing the strain rate values from 300 to $0 \mathrm{~s}^{-1}$ (down curve) and increasing it again from 0 to $300 \mathrm{~s}^{-1}$ (up curve 2) to verify and guarantee the elimination of thixotropic effects. For the characterization of the rheological behavior, only the data from the $2^{\text {nd }}$ up were 
analyzed (BARNES, 1997). The flow curves were determined under four different temperatures, $5,25,45$, and $65^{\circ} \mathrm{C}$. These temperatures had been selected because of their extensive use in the food industry, for example, 5 and $25^{\circ} \mathrm{C}$ are used in storage and $65^{\circ} \mathrm{C}$ in processes such as pasteurization and others. The temperature control was assured by a Peltier system installed in the inferior plate of the rheometer.

\subsection{Rheological equations}

The mathematical analysis of the rheograms obtained from the analyzed samples was made with the use of the Statistica 5.0 software. The experimental data were applied to the rheological equations with the best fit based on the coefficient of determination $\left(\mathrm{R}^{2}\right)$.

The rheological behavior of the samples was characterized by Ostwald-de-Waele (Power Law), Herschel-Bulkley (HB), and Mizhari Berk rheological equations, represented by Equations (3), (4), and (5), respectively.

Power Law: $\sigma=k \cdot \dot{\gamma}^{n}$

Herschel-Bulkley: $\sigma=\sigma_{0}+k \cdot \dot{\gamma}^{n}$

Mizhari Berk: $\sigma^{0,5}-k_{0 M}=k_{M} \cdot(\dot{\gamma})^{n_{M}}$

where $\sigma$ is the the shear stress $(\mathrm{Pa}) ; \dot{\gamma}$ the shear rate $\left(\mathrm{s}^{-1}\right) ; k$ and $k_{\mathrm{M}}$ are the consistency coefficients $(\mathrm{Pa})^{1 / 2}(\mathrm{~s})^{\mathrm{n}} ; \mathrm{n}$ and $\mathrm{n}_{\mathrm{M}}$ the flow behavior indexes, $\sigma_{0}$ the yield stress, and $k_{0 \mathrm{M}}$ the square root of the yield stress $(\mathrm{Pa})^{1 / 2}$.

\section{Results and discussion}

\subsection{Physical and physicochemical characterization}

The results of the physical and the physicochemical characterization of blueberries are shown in Tables 1 and 2, respectively. There is a large range of values for the anthocyanins concentration in blueberry fruits reported in the literature. Stojanovic et al. (2007) found $136 \mathrm{mg} .100 \mathrm{~g} \mathrm{~g}^{-1}$ (dry matter) of anthocyanins in rabbiteye blueberry (Vaccinium ashei Reade), which is similar to the value found by Prior et al. (1998) (124 mg.100 g $\mathrm{g}^{-1}$ ) but differs considerably from the results reported by Moyer et al. (2002). They report a mean value of $406 \mathrm{mg} .100 \mathrm{~g} \mathrm{~g}^{-1}$, which was higher than those found in any other blueberry variety. In this work the total anthocyanins was $156.20 \mathrm{mg} .100 \mathrm{~g}^{-1}$, and this result is the same as those found by other authors.

Environmental factors that influence the formation of anthocyanins (e.g., light, temperature, agronomic practices,

Table 1. Physical characteristics of blueberry fruits.

\begin{tabular}{lc}
\hline Paramenter & Values \\
\hline Weight $(\mathrm{g})$ & $0.86 \pm 0.30$ \\
Diameter $(\mathrm{mm})$ & $11.07 \pm 1.34$ \\
Height $(\mathrm{mm})$ & $9.17 \pm 1.24$ \\
\hline
\end{tabular}

and various stresses) may have contributed to the differences between the results in those studies. Single genotypes of blueberries were reported to differ in the anthocyanin contents by $30 \%$ between seasons (KALT; MCDONALD, 1996). The storage of blueberries in the fresh state prior to freezing and the anthocyanins extraction and determination can have a great influence on the final results (KALT et al., 1999).

The moisture was lower than the value found by Stojanovic et al. (2007) (86,3\% wet basis) and the water activity was higher than that found by the same author.

\subsection{Rheological properties}

Figure 1 represents a typical flow curve of blueberry at $25^{\circ} \mathrm{C}$. As shown in Figure 1, it is possible to observe a peak on the flow curve referring to the first cycle of shear denominated overshoot. When a shear rate is suddenly imposed on a viscoelastic fluid held previously at rest, the shear stress shows an initial peak before reaching the steady-state value (STEFFE, 1996). This peak on the stress value at the beginning of the flow represents the breakdown on the structure of the material.

The breakdown on the structure due to the shear applied, resulting the decrease of the viscosity, can be observed by the difference between the flow curves at different cycles of shear, an increase on the shear stress (Ascent 1 ) followed by a decrease on stress (Descending) and, after that, another increase of the shear stress (Ascent 2) indicating the presence of thixotropy, characteristic of a large part of the fluids and vegetable pastes.

Figure 1 also allows the verification that the beginning of the last cycle of the shear applied (Ascent 2) coincided with the final of the previous cycle (Descending) evidencing that the thixotropy of the system was eliminated after the first ascent of shear stress.

The flow curves at four different sample temperatures are shown in Figure 2 and the parameters of adjustment are presented in Table 3 . All models presented the best adjustment of the data showing very good values for the coefficient of determination for the 5,25 , and $45^{\circ} \mathrm{C}\left(\mathrm{R}^{2}>0.987\right)$.

The $65^{\circ} \mathrm{C}$ sample, however, did not show a $\mathrm{R}^{2}$ value close to the unit in all models applied and a great dispersion of the

Table 2. Composition of whole fresh blueberry fruits from Brazil.

\begin{tabular}{lr}
\hline \multicolumn{1}{c}{ Parameters } & \multicolumn{1}{c}{ Values } \\
\hline Moisture $\left(\mathrm{g} .100 \mathrm{~g} \mathrm{~g}^{-1}\right)($ wet basis) & $82.12 \pm 0.54$ \\
Total sugar $\left(\mathrm{g} .100 \mathrm{~g}^{-1}\right)$ & $10.67 \pm 0.09$ \\
Invert sugar $\left(\mathrm{g} .100 \mathrm{~g}^{-1}\right)$ & $10.61 \pm 0.10$ \\
Protein $\left(\mathrm{g} .100 \mathrm{~g}^{-1}\right)$ & $0.52 \pm 0.02$ \\
Ash $\left(\mathrm{g} .100 \mathrm{~g}^{-1}\right)$ & $0.20 \pm 0.01$ \\
Carbohydrate $\left(\mathrm{g} .100 \mathrm{~g} \mathrm{~g}^{-1}\right)$ & $17.05 \pm 0.21$ \\
Soluble solids $\left({ }^{\circ}\right.$ Brix $)$ & $14.46 \pm 0.10$ \\
Acidity $\left(\mathrm{g}_{\text {citric acid }} .100 \mathrm{~g}^{-1}\right)$ & $0.66 \pm 0.01$ \\
pH & $2.98 \pm 0.04$ \\
Total anthocianins $\left(\mathrm{mg} 100 \mathrm{~g}^{-1}\right)$ & $156.20 \pm 6.64$ \\
Water activity & $0.983 \pm 0.003$ \\
\hline
\end{tabular}



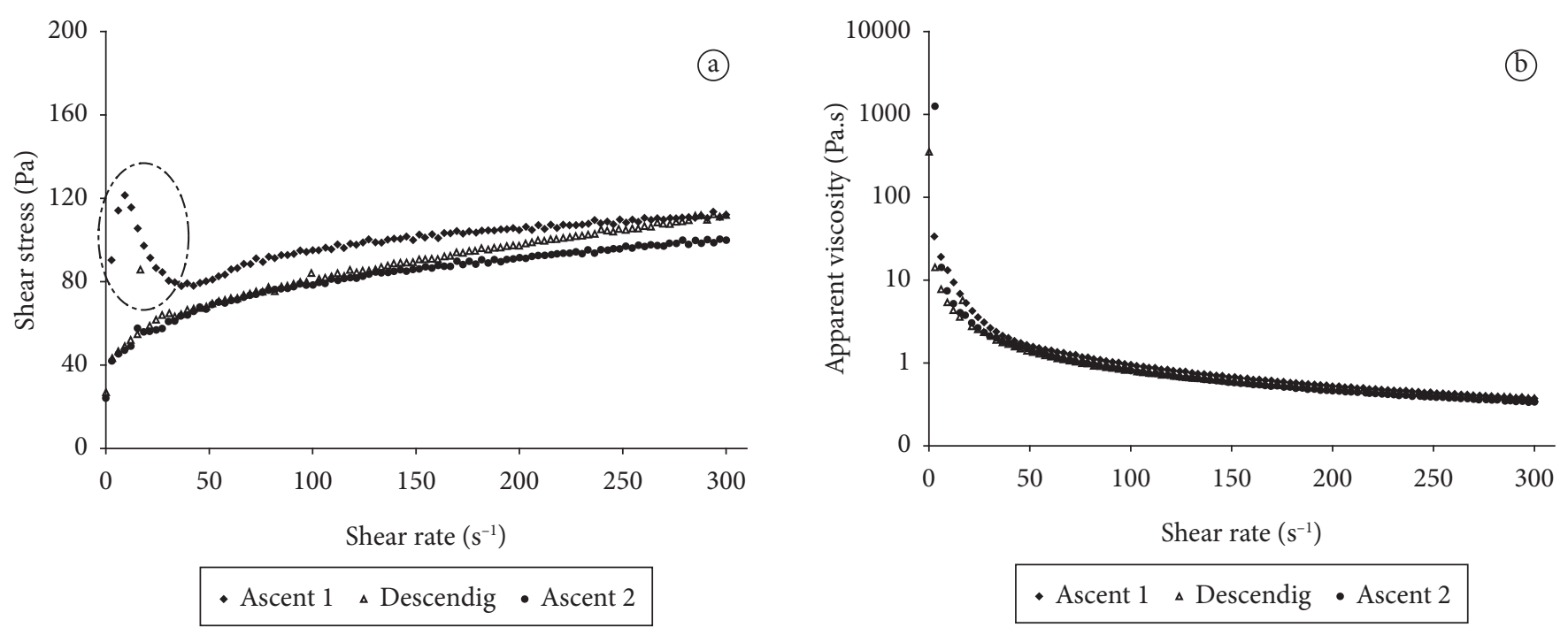

Figure 1. Flow curve for blueberry at $25^{\circ} \mathrm{C}$ : a) Shear stress as a function of the shear rate; and b) apparent viscosity as a function of the shear rate.
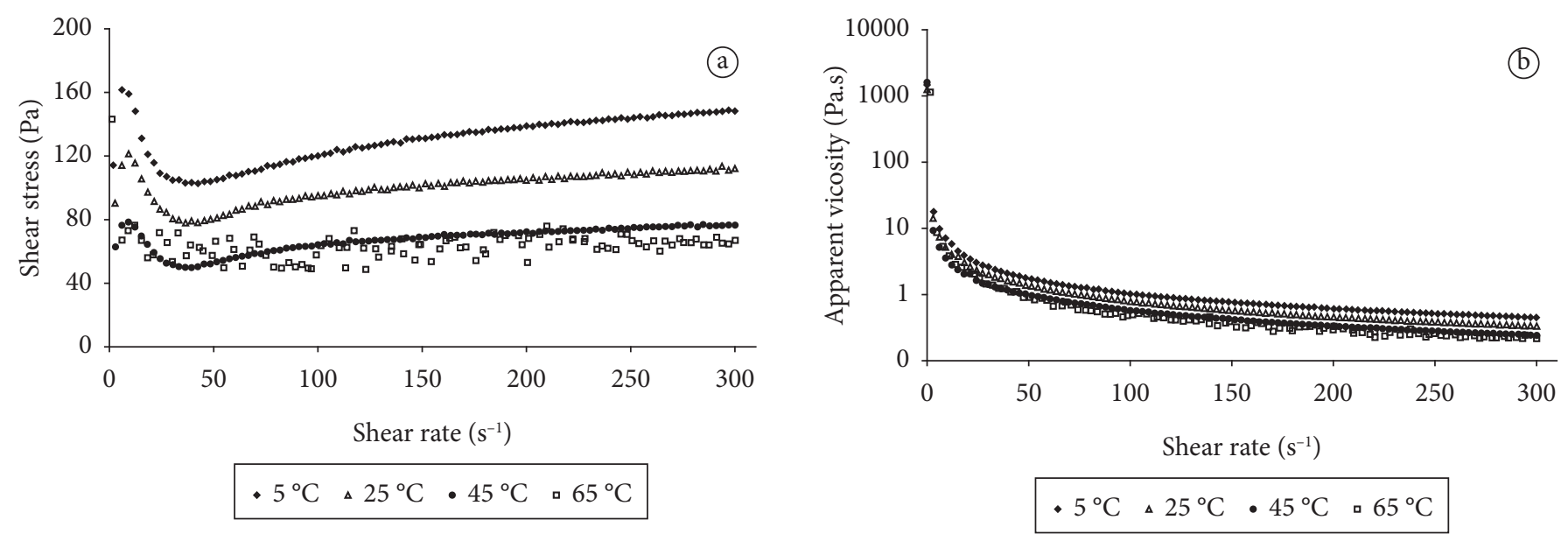

Figure 2. Flow curve for blueberry at different temperatures: a) Shear stress as a function of the shear rate; and b) apparent viscosity as a function of the shear rate.

data at this temperature was observed. This behavior is due to the large amount of particles in suspension (solids dispersed in the liquid phase) that have the mobility increased with an increase in the temperature since the viscosity of the liquid phase had decreased.

The behavior index $n$ is smaller than one indicating a non-Newtonian (pseudoplastic) behavior, in this case with the existence of yield stress. This behavior was observed by other authors, Grabowski et al. (2008) with sweet potato puree, Bhattacharya et al. (1999) with mustard paste.

The yield stress and behavior index decreased with an increase in the temperature for 5,25 , and $45^{\circ} \mathrm{C}$ whereas for $65^{\circ} \mathrm{C}$ the effects were the opposite exhibiting elevated values. The viscosity of all samples decreased with an increase in the temperature.

A pseudoplastic behavior was also found in a great number of rheological characterizations of food materials: raspberry, strawberry prune, and peach purees (MACEIRAS et al., 2007); pineapple and mango pulps (PELEGRINE et al., 2002), and this behavior was already reported for blueberry (Vaccinium corymbosum L.) in a study conducted by Nindo et al. (2007).

According to Table 4, generally there is a decrease in the yield stress and in the behavior index as temperature increases, 
Table 3. Adjustment of experimental data to Power Law, HerschelBulkley and Mizhari Berk models.

\begin{tabular}{|c|c|c|c|}
\hline Model & $\mathrm{T}\left({ }^{\circ} \mathrm{C}\right)$ & Equation & $\mathrm{R}^{2}$ \\
\hline \multicolumn{4}{|l|}{ Power Law } \\
\hline & 5 & $\sigma=37.079 \cdot \dot{\gamma}^{0.225}$ & 0.987 \\
\hline & 25 & $\sigma=30.541 \cdot \dot{\gamma}^{0.207}$ & 0.991 \\
\hline & 45 & $\sigma=20.993 \cdot \dot{\gamma}^{0.218}$ & 0.989 \\
\hline & 65 & $\sigma=24.951 \cdot \dot{\gamma}^{0.158}$ & 0.739 \\
\hline \multicolumn{4}{|c|}{ Herschel-Bulkley } \\
\hline & 5 & $\sigma=31.757+14.817 \cdot \dot{\gamma}^{0.341}$ & 0.998 \\
\hline & 25 & $\sigma=14.465+17.196 \cdot \dot{\gamma}^{0.276}$ & 0.997 \\
\hline & 45 & $\sigma=9.837+13.604 \cdot \dot{\gamma}^{0.270}$ & 0.993 \\
\hline & 65 & $\sigma=37.015+0.519 \cdot \dot{\gamma}^{0.696}$ & 0.787 \\
\hline \multicolumn{4}{|l|}{ Mizhari Berk } \\
\hline & 5 & $\sigma^{0.5}=5.2536+1.5904 \cdot \dot{\gamma}^{0.2445}$ & 0.998 \\
\hline & 25 & $\sigma^{0.5}=3.6646+2.2436 \cdot \dot{\gamma}^{0.1826}$ & 0.996 \\
\hline & 45 & $\sigma^{0.5}=2.5351+2.3153 \cdot \dot{\gamma}^{0.1680}$ & 0.992 \\
\hline & 65 & $\sigma^{0.5}=6.0386+0.0608 \cdot \dot{\gamma}^{0.6126}$ & 0.788 \\
\hline
\end{tabular}

Table 4. Parameters of the adjustment with Herschel-Bulkley model for blueberry puree at different temperatures.

\begin{tabular}{crrcc}
\hline $\mathrm{T}\left({ }^{\circ} \mathrm{C}\right)$ & $\sigma_{\mathrm{o}}(\mathrm{Pa})$ & $\mathrm{k}\left(\mathrm{Pa} . \mathrm{s}^{\mathrm{n}}\right)$ & $\mathrm{n}$ & $\mathrm{R}^{2}$ \\
\hline 5 & 31.757 & 14.817 & 0.341 & 0.998 \\
25 & 17.465 & 17.196 & 0.276 & 0.997 \\
45 & 9.837 & 13.604 & 0.270 & 0.993 \\
65 & 37.015 & 0.519 & 0.696 & 0.787 \\
\hline
\end{tabular}

except for the $65^{\circ} \mathrm{C}$ sample which showed the opposite behavior and discrepant values.

The fact that viscosity decreases with an increase in the shear rate, behavior observed in pseudoplastic materials, is due to the progressive increase in the shear velocity that breaks the arrangement of long chain molecules and helps to surpass the intermolecular resistance to the flow (HOLDSWORTH, 1971).

The Arrhenius equation (Equation 1) relates the effect of the temperature in the viscosity of various liquid foods (GRIGELMO-MIGUEL et al., 1999). For non-Newtonian materials, the apparent viscosity can be used in this relation. The Arrhenius equation was applied to the data observed for a $100 \mathrm{~s}^{-1}$ shear rate, as shown in Figure 3. The adjustments parameters are shown in Table 5.

The blueberry showed activation energy of $9.39 \mathrm{~kJ} . \mathrm{mol}^{-1}$, which is a low value due to the high content of solids within
Table 5. Parameters for the adjustment to Arrhenius equation.

\begin{tabular}{cccc}
\hline Model & $\mathrm{E}_{\mathrm{a}}\left(\mathrm{kcal}_{\mathrm{gmol}}{ }^{-1}\right)$ & $\mathrm{B}$ & $\mathrm{R}^{2}$ \\
\hline $\ln \eta=\left(\frac{E_{a}}{R}\right) \cdot T^{-1}+B$ & 2.2410 & -4.3764 & 0.99 \\
\hline
\end{tabular}

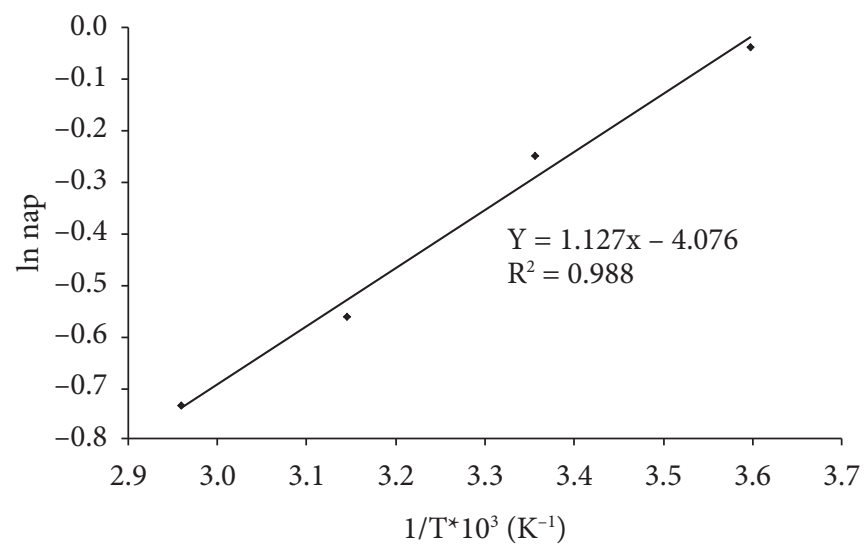

Figure 3. Effect of the temperature on the apparent viscosity $\left(100 \mathrm{~s}^{-1}\right)$ of blueberry.

the dispersion. Fruits with high amounts of solids in dispersion present inferior values for the activation energy than clarified juices or juices with less concentration of solids.

\section{Conclusions}

Blueberry presented a non-Newtonian (pseudoplastic) behavior with the existence of yield stress and the experimental data was well fitted in Ostwald-de-Waele (Power Law), HerschelBulkley (HB) and Mizhari Berk models, presenting high values for the coefficient of determination $\left(\mathrm{R}^{2}\right)$, except for the $65^{\circ} \mathrm{C}$ sample that showed a much dispersed experimental data because of the high amount of dispersed solids. The sample temperature influences the rheological behavior, the viscosity decreased with an increase in the temperature, and this relation for the blueberry was well described by the Arrhenius equation. The activation energy at constant shear rate of $100 \mathrm{~s}^{-1}$ was $9.36 \mathrm{~kJ} \cdot \mathrm{mol}^{-1}$.

\section{Acknowledgements}

The authors would like to thank UNICAMP, FAPESP, CNPq and Nutrisaúde Indústria e Comércio de Frutas Ltda.

\section{References}

ASSOCIATION OF OFFICIAL ANALYTICAL CHEMISTRY - AOAC. Official methods of analysis. 14 ed. Washington, D. C., 1984.

BHATTACHARYA, S.; VASUDHA, N.; MURTHY, K. S. K. Rheology of mustard paste: a controlled stress measurement. Journal of Food Engineering, v. 41, n. 3-4, p. 187-191, 1999.

FRANCIS, F. J. Analysis of anthocyanins. In: MARKAIS, P. Anthocyanins as food colors. New York: Academic Press, 1982. p. 281-207. 
GRABOWSKI, J. A.; TRUONGA, V. D.; DAUBERT, C. R. Nutritional and rheological characterization of spray dried sweet potato powder. Lebensmittel-Wissenschaft und-Technologie, v. 41, p. 206-216, 2008.

GRIGELMO-MIGUEL, N.; IBARZ-RIBAS, A.; MARTÍN-BELLOSO, O. Rheology of peach dietary fibre suspensions. Journal of Food Engineering, v. 39, n. 1, p. 91-99, 1999.

HAMINIUK, C. W. I. et al. Influence of temperature on the rheological behavior of whole araçá pulp (Psidium cattleianum sabine). Food Science and Technology, v. 39, p. 426-430, 2006.

HOLDSWORTH, S. D. Aplicability of rheological models to the interpretation of flow and processing behaviour of fluid food products. Journal of Texture Studies, v. 2, n. 4, p. 393-418, 1971.

KALT, W. et al. Antioxidant capacity, vitamin C, phenolics, and anthocyanins after fresh storage of small fruits. Journal of Agricultural and Food Chemistry, v. 47, n. 11, p. 4638-4644, 1999.

KALT, W.; MCDONALD, J. E. Chemical composition of lowbush blueberry cultivars. Journal of the American Society for Horticultural Science, v. 121, p. 142-146, 1996.

MACEIRAS, R.; ÁlVAREZ, E.; CANCELA, M. A. Rheological properties of fruit purees: effect of cooking. Journal of Food Engineering, v. 80, n. 3, p. 763-769, 2006.

MOYER, R. A. et al. Anthocyanins, phenolics, and antioxidant capacity in diverse small fruits: Vaccinium, Rubus, and Ribes. Journal of Agricultural and Food Chemistry, v. 50, p. 519-525, 2002.
NAKAMURA, Y. et al. Dihydrochalcones: evaluation as novel radical scavenging antioxidants. Journal of Agricultural and Food Chemistry, v. 51, n. 7, p. 3309-3312, 2003.

NINDO, C. I. et al. Rheological properties of blueberry puree for processing applications. Food Science and Technology, v. 40, n. 2, p. 292-299, 2007.

PELEGRINE, D. H.; SILVA, F. C.; GASPARETTO, C. A. Rheological behavior of pineapple and mango pulps. Lebensmittel-Wissenschaft und-Technologie, v. 35, n. 8, p. 645-648, 2002.

PRIOR, R. L. et al. Antioxidant capacity as influenced by total phenolics and anthocyanins content, maturity, and variety of Vaccinium species. Journal of Agricultural and Food Chemistry, v. 46, n. 7, p. 2686-2693, 1998.

RAO, M. A. Rheology of liquid foods - A review. Journal of Texture Studies, v. 8, n. 2, p. 135-168, 1977.

RAO, M. A.; STEFFE, J. F. Viscoelastic Properties of Foods. New York: Elsevier Applied Science, 1992. p. 441.

STEFFE, J. F. Rheological methods in food process engineering. 2 ed. USA: Freeman Press, 1996.

STOJANOVIC, J.; SILVA, J. L. Influence of osmotic concentration, continuous high frequency ultrasound and dehydration on antioxidants, colour and chemical properties of rabbiteye blueberries. Food Chemistry, v. 101, p. 898-906, 2007. 